\title{
Malignant Germinomatous Cells Present
}

National Cancer Institute

\section{Source}

National Cancer Institute. Malignant Germinomatous Cells Present. NCI Thesaurus. Code C123865.

A morphologic finding indicating the presence of germinoma, dysgerminoma, or seminoma germ cells. 